\title{
1 Habitat and biodiversity of on-farm water storages: A case study in South-East Queensland,
}

\section{Australia}

3 (Shortened title: Habitat and biodiversity of on-farm water storages)

Australian Rivers Institute, Griffith School of Environment, Nathan, QLD 4111, Australia.

*Corresponding author: email.c.fellows@griffith.edu.au, Ph. +61 73735 3840, Fax.+61 737357615

Abstract

On-farm water storages (locally known as farm dams or farm ponds) are an important part of many agricultural landscapes as they provide a reliable source of water for irrigation and stock. Although these waterbodies are artificially constructed and morphologically simple, there is increasing interest in their potential role as habitat for native flora and fauna. In this paper, we present results from a case study which examined the habitat characteristics (such as water physical and chemical parameters, benthic metabolism, and macrophyte cover) and the macrophyte and macroinvertebrate biodiversity of eight farm ponds on four properties in the Stanley Catchment, South-East Queensland, Australia. Each landowner was interviewed to allow a comparison of the management of the ponds with measured habitat and biodiversity characteristics, and to understand landowners' motivations in making farm pond management decisions.

The physical and chemical water characteristics of the study ponds were comparable to the limited number of Australian farm ponds described in published literature. Littoral zones supported forty-five macroinvertebrate families, with most belonging to the orders Hemiptera, Coleoptera, Odonata and Diptera. Invertebrate community composition was strongly influenced by littoral zone macrophyte structure, with significant differences between ponds with high macrophyte cover compared to those 
with bare littoral zones. The importance of littoral zone macrophytes was also suggested by a

significant positive relationship between invertebrate taxonomic richness and macrophyte cover.

The landowners in this study demonstrated sound ecological knowledge of their farm ponds, but many had not previously acknowledged them as having high habitat value for native flora and fauna. If managed for aquatic organisms as well as reliable water sources, these artificial habitats may help to maintain regional biodiversity, particularly given the large number of farm ponds across the landscape.

Key words: Farm pond, aquatic invertebrates, macrophytes, management, agriculture

Much of the land available for terrestrial habitat is now used for agriculture, contributing to biodiversity loss through its conversion of complex natural systems to simplified managed systems (Altieri 1999; Tscharntke and others 2005; Reidsma and others 2006). Agricultural activities have therefore usually conflicted with nature conservation (Tress 2002). However, recent research suggests that appropriate agricultural management can enhance biodiversity in these modified environments, contributing to conservation efforts (Tscharntke and others 2005). Most of this research has been based in terrestrial environments, although waterbodies (dams, ponds and wetlands) in agricultural areas have been found to have the potential to sustain both local and regional biodiversity in the few studies that have focused on these environments (Williams and others 2003; Hazell and others 2004; Robson and Clay 2005).

Farm ponds are now part of many agricultural landscapes, especially where there is a need for reliable water supply, such as Australia (Casanova and others 1997; Brock and others 1999; Hazell and others 2004). Construction of ponds with the goal of water reliability creates water bodies that are usually fairly small, deep and steep-sided and therefore contain less shallow edge habitat than natural water bodies (Brock and others 1999; Hazell and others 2004). Nevertheless, a range of aquatic organisms have been found in ponds, especially those with greater habitat complexity due to the presence of littoral zone plants (Timms 1980; Frankenberg 1998; Hazell and others 2001; Nicolet and others 
2004). In addition to morphological characteristics, the ability of ponds to support aquatic organisms depends on water quality and ecosystem processes that support food webs (i.e. primary production) (Platt and Corrick 1994; Brainwood and others 2004). If farm ponds are able to provide suitable habitat for native flora and fauna, they may play an important role in the conservation of native biodiversity in agricultural landscapes in which natural water bodies, such as wetlands, typically have been degraded or lost (Casanova and others 1997; Hazell and others 2004).

In the agricultural landscape, it is also important to look at the influence of property management on the biodiversity and potential conservation value of farm ponds. There have been a limited number of studies addressing these issues. Hazell and others $(2001 ; 2004)$ acknowledged that farm ponds might help conserve frogs across the landscape, and that landowners had the capacity to increase the conservation value of ponds through management. It is important to recognise that farm management decisions are complex, with many underlying determinants influencing farmers' attitudes and motivations towards farm management decisions (Rickson and others 1987; Beedell and Rehman 1999; Lisson and others 2003). Rickson and others (1987) also documented that the landowner's perception of the conservation value of their land is also important when making these management decisions and have evaluated farmers' perceptions of erosion on their properties, comparing measured erosion to perceived erosion as estimated by landowners. To-date, this has not been done to measure landowners perceptions of the conservation value of their farm ponds.

There is currently a lack of information on the potential of farm ponds to support native biodiversity and how landowner's farm management strategies may influence this biodiversity. This case study aimed to discover if farm ponds in South-East Queensland could support native flora and fauna and to uncover if management of these storages could increase their biodiversity value and how landowners might be motivated to undertake these strategies. The first objective of the study was to assess the

81 biodiversity and habitat value of on-farm water storages on cattle properties in South-East Queensland.

82 We also sought to examine the factors that influence habitat, biodiversity, and the links between them, 83 such that we could make recommendations on how these systems might be managed to increase their 
ecological value. Finally, we interviewed landowners to examine their motivations to manage their farm ponds as well as their perception of their water storages as habitat for native species. Combining ecological science with social science in this case study was undertaken with the aim of understanding the scope for change in management practices towards increasing the conservation value of farm ponds.

\section{Methods}

\section{Study area}

The potential conservation value of farm ponds in South-East Queensland, Australia was evaluated by sampling a number of ponds in the Stanley River catchment (Figure 1). The catchments total area is $1,527 \mathrm{~km}^{2}$, which includes $1,045 \mathrm{~km}$ of stream length. Water supply is the dominant land use as two major water supply dams, Wivenhoe Dam and Somerset Dam, are located in this catchment. The other predominant land use is rural, with beef and dairying encompassing most of the central and lower sections of the catchment (Waterways 2002; QNRM 2003). The upper catchment is relatively undisturbed, dominated by natural forests with some forestry plantations (Waterways 2002; QNRM 2003).

The South-East Queensland region has a sub-tropical climate with annual rainfall dominated by the summer months. In the Stanley River catchment, summer months (December to February) have an average maximum temperature of $30^{\circ} \mathrm{C}$, while during winter (June to August), minimum temperatures may drop under $9^{\circ} \mathrm{C}$ (Loi and Malcolm 1998; BOM 2005b). Average rainfall for the catchment is around $1350 \mathrm{~mm} / \mathrm{year}$. In Kilcoy (situated in the western plains of the catchment), the summer rainfall (Dec to Feb) averages 115-140 mm/month, while in the drier winter months (May-Sept), monthly rainfall was less than $60 \mathrm{~mm}$ for the period 1890-1993 (Loi and Malcolm 1998). This variability, combined with high evaporation rates, increases demand for water supply in winter and has led to the development of 323 water storages in the catchment that capture overland flow (QNRM 2003). These storages have a combined volume of 793 megalitres with most (95\%) having a surface area of $\leq 5000$ $\mathrm{m}^{2}$ and a volume of less than 5 megalitres. 
114 Landowners interested in participating in this case study were found via the Brisbane Valley-Kilcoy

115 Landcare group. Four landowners (A, B, C and D) in the Stanley River catchment were selected for 116 this study due to their willingness to partake in interviews and the presence of multiple farm ponds on

117 their property. A preliminary visit was carried out to each property to select 2 ponds to use in this

118 study, based on size and surrounding land use. Two ponds on each property were chosen (1 and 2)

119 and all eight ponds were fairly similar in size and were surrounded by land used for cattle grazing.

120 Sampling was carried out during July 2004.

122 Habitat characteristics included measurement of pond morphology, water physical and chemical 123 characteristics, benthic metabolism and littoral zone structural complexity (as measured by 124 macrophyte cover). Ponds were surveyed for perimeter, surface area and littoral zone slope (as 125 measured by the change in depth $(\mathrm{cm}) /$ distance from the shore $(\mathrm{cm}))$. Dissolved oxygen and 126 temperature were recorded for 24 hours by a TPS logger (WP-82Y) at 2 depths $(<5 \mathrm{~cm}$ and $>70 \mathrm{~cm})$.

127 Photic depth was defined as the depth where one percent incident light remained (Wetzel and Likens 128 1991) and was measured by a depth profile taken at midday with a LICOR quantum sensor (LI-192) 129 and data logger (LI-1400). Spot measures of conductivity, $\mathrm{pH}$, and turbidity were also recorded.

130 Depth integrated water samples were collected at each of the ponds at the time of sampling and 131 analysed for nutrient concentrations (total nitrogen (TN), total phosphorus (TP), filterable reactive 132 phosporus (FRP), ammonium nitrogen $\left(\mathrm{NH}_{4}{ }^{+}\right)$, nitrogen oxides $\left.\left(\mathrm{NO}_{3}^{-}\right)\right)$. Soluble nutrients were 133 measured on an automated LACHAT 8000QC flow injection system using the following methods: 134 ascorbic acid reduction of phosphomolybdate for FRP; cadmium reduction of nitrate to nitrite by 135 diazotizing the nitrite with sulfanilamide and coupling with $\mathrm{N}$ - (1-naphthyl) ethylenediamine 136 dihydrochloride for $\mathrm{NO}_{3}{ }^{-}$and $\mathrm{NO}_{2}{ }^{-}$; production of the indophenol blue colour complex for $\mathrm{NH}_{4}{ }^{+}$

137 (Greenberg and others 1992). Total nutrient samples were digested using a persulfate digestion 138 procedure, after which analyses were performed as described above for soluble nutrients (Greenberg 139 and others, 1992). Surface waters typically have very little nitrite, and therefore nitrogen oxides will 
140 be referred to as nitrate $\left(\mathrm{NO}_{3}{ }^{-}\right)$. Chlorophyll $a$ was measured as a relative measure of phytoplankton

141 biomass. Water column samples of known volume were filtered using glass fibre filters $(0.7 \mu \mathrm{m})$, and

142 absorbance was measured on a spectrophotometer (Shimadzu Model 1601) following extraction of the

143 filter in a 90\% alkaline acetone solution. Samples were acidified for phaeophytin correction (Wetzel

144 and Likens 1991; Goldsborough 2001). Additional information about the ponds (for example, pond

145 age) was obtained from each of the landowners.

146

147 Sampling within the ponds was focused on the littoral zones for benthic metabolism, vegetation and

148 biota, due to sampling accessibility and the known high diversity and productivity of these areas

149 (Brock and others 1999). Littoral zones were defined in this study as the submerged area from the

150 water's edge to one metre horizontally out from the shoreline. Benthic metabolism was measured with

151 in-situ recirculating clear perspex chambers with an attached oxygen probe (Fellows and others 2006).

152 Chambers were deployed in the littoral zone sediment between the hours of 9:30 am and 5:00 pm. A

153 data logger (TPS model WP-82Y) recorded measurements of the dissolved oxygen and temperature of

154 the water in the chamber every ten minutes. After at least two hours of midday sunlight, the chambers

155 were covered with opaque, reflective material to make them completely dark to measure the rate of

156 respiration (Fellows and others 2001). The rate of change of DO over time was used to calculate the

157 combined rates of oxygen consumption and production (net ecosystem production (NEP)) during the

158 daylight period, and the rate of oxygen uptake (respiration (R)) during the darkened period. Gross

159 primary production (GPP) was calculated as the difference between the two rates. The hourly rates

160 were extrapolated to represent daily rates in order to calculate GPP/R ratios. GPP rates were

161 multiplied by the average daylight hours for July in South-East Queensland (seven hours; BOM

162 2005a), and respiration rates were multiplied by 24 hours.

163

164 For vegetation and macroinvertebrate sampling, the major habitats present in the pond littoral zones

165 were identified (eg. dense macrophytes, bare) and composite samples were taken from three $20 \mathrm{~m} \times 1$

$166 \mathrm{~m}$ transects. Along each transect, all macrophyte species were identified and densities visually

167 estimated as percent cover of emergent, floating and submerged macrophytes. These were recorded 
separately and then added to obtain an overall percentage cover. Transects were also sampled for

macroinvertebrates with a D-framed dip net. The net contents were drained of excess water and $100 \%$ ethanol was added resulting in a final concentration of approximately $70 \%$ (Cummins and Merritt 2001). Sorting was conducted in the laboratory after washing through three sieves $-1 \mathrm{~cm}, 1000 \mu \mathrm{m}$ and $250 \mu \mathrm{m}$. The three fractions retained on the sieves were sorted by eye in the laboratory and then identified to the greatest resolution possible with the use of a dissecting microscope. Invertebrate data is presented in this paper at the family level so comparisons could be made with data collected from nearby streams by the South-East Queensland environmental health monitoring program (EHMP). Invertebrate data collected 2002-2003 from 10 streams located near the study ponds was used for this comparison. For all taxonomic groups, introduced (non-native) taxa were identified and recorded.

\section{Landowner interviews}

180 Interviews were organised with each of the landowners to gain knowledge about the use and management of the ponds, as well as the ecological knowledge the landowner had regarding their farm ponds. These interviews were structured, consisting of a set of pre-established questions in a questionnaire format, enabling comparisons between landowner responses. Landowners were asked to rank factors that may influence their decisions on farm pond management on a scale of importance

185 from one to ten $(10=$ most important $)$. Landowner knowledge of habitat and biodiversity values of

186 their farm ponds was examined by asking them to predict the biodiversity of their storages given the

187 following categories: poor, fair, good, very good (ranked from $1=$ poor to $4=$ very good). These

188 closed questions which asked the participant to rank the strength of their opinion were usually

189 followed by an open question to provide more information on the strength of these attitudes and to

190 allow the participant to address alternatives that were not included in the previous closed question

191 (Schuman and Presser 1981; Babbie 1990, Nichols 1991). All questionnaires were conducted by a

192 common interviewer (KM), ensuring a standardised approach to data collection. Because the

193 interviewer was present while the questionnaire was completed, any ambiguous questions were

194 carefully explained and all questions were answered. The interviewer was also able to further explore 
answers that lacked precision (Bentham 1982). In summary, using a questionnaire containing mostly

196 closed questions and administering it personally reduced the potential error and variability of the data

197 collected in these interviews (Sudman and Bradburn 1974; Schuman and Presser 1981; Denzin and

198 Lincoln 2003).

\section{Data Analysis}

201 Taxonomic richness is presented both as the total taxonomic richness of the pond (the total number of 202 taxa found in all transects) and as a transect mean value with standard error. Richness and diversity 203 measures are presented and analysed at the species level for macrophytes and at the family level for

204 invertebrates. Shannon diversity indices have been used as biodiversity measures, and are reported as 205 the mean value with associated standard error. Tests for normality revealed that much of the data did 206 not have normal distributions, even after transformations. Therefore nonparametric univariate 207 statistics were chosen and the analyses were carried out in SAS Version 8 (SAS 1999), using a 208 significance level of $\mathrm{p}<0.05$. Nonparametric ANOVAs (Kruskal Wallis tests using Wilcoxon scores) 209 were used to investigate differences among the ponds in benthic metabolism, and taxomonic richness 210 and biodiversity of macroinvertebrates (family level) and macrophytes (species level) as well as

211 macrophyte \% cover. Site (pond) was used as the main factor (eight levels) and multiple

212 measurements within each site were used as replicates. Bonferroni (Dunn) t-tests were further used to 213 identify statistical differences between ponds $(\mathrm{p}<0.05)$. Spearman's rank correlation was used to 214 investigate relationships between habitat characteristics, such as turbidity, photic depth, macrophyte 215 species richness and macrophyte abundance, as well as between habitat characteristics and measured 216 aquatic biodiversity, such as littoral zone \% cover and invertebrate richness. The relationship between 217 the total aquatic diversity of the pond (macrophyte + invertebrate richness) and the age and size of the 218 pond was also investigated.

220 Differences among invertebrate community composition of the ponds were explored using

221 multivariate analyses based on abundance data. A stress of 0.2 or less was considered low stress, and 222 therefore supportive of a strong pattern. Analysis of Similarity (ANOSIM), using the Bray Curtis 
association measure, was performed on abundance data using PRIMER. SIMPER analyses were used

to identify which taxonomic groups were responsible for observed differences in community structure.

Landowner interview questions which required the landowner to rank their responses provided quantitative results which could be analysed. These values were averaged across all landowners and are presented as the mean value with its associated standard error. The relationship between the landowners' predictions of the biodiversity of their ponds and the measured total aquatic biodiversity was tested using Spearman's rank correlation.

\section{Results}

\section{Habitat characteristics}

234 The ponds differed in morphology and history, but had physical and chemical characteristics which could support aquatic organisms. The study ponds ranged from $282 \mathrm{~m}^{2}$ to $1259 \mathrm{~m}^{2}$ in surface area with perimeters between $70 \mathrm{~m}$ and $180 \mathrm{~m}$ (Table 1). Littoral zone slope also varied across the study ponds. The age of the ponds ranged from 2 to 65 years since construction. Only 3 of the ponds had any structural farm pond management strategies in place. A1 and B1 both had vegetation planted near them and D2 had fencing around it. Dissolved oxygen concentrations in the farm ponds did not drop

240 below critically low levels at night, as demonstrated by $3.05 \mathrm{mg} \mathrm{L}^{-1}$ being the lowest dissolved oxygen 241 reading recorded (deep water, pond A1). There were generally moderate swings in both temperature

242 and dissolved oxygen over 24 hours. Shallow water diel temperature swings were larger in

243 magnitude than the deeper water due to warming of the shallow water layer during the day. The

244 changes in dissolved oxygen over 24 hours were generally similar in the shallow and deep water. All 245 ponds had circumneutral $\mathrm{pH}$ (5.73 in $\mathrm{C} 2$ to 7.75 in $\mathrm{B} 2)$ and had quite high light penetration with photic depths over $1 \mathrm{~m}$, except for pond $\mathrm{C} 1$.

248 Although nutrient levels were reasonably low across the ponds, they did not seem to be at levels which 249 would limit primary production. $\mathrm{C} 1$ had much a much higher concentration of $\mathrm{TP}\left(0.14 \mathrm{mg} \mathrm{P} \mathrm{L}{ }^{-1}\right)$ than the other ponds $\left(0.014\right.$ to $\left.0.056 \mathrm{mg} \mathrm{P} \mathrm{L}^{-1}\right)$ and dissolved inorganic nitrogen levels in $\mathrm{D} 1 \mathrm{NH}_{4}{ }^{+}=$ 
$0.8, \mathrm{NO}_{3}^{-}=0.064 \mathrm{mg} \mathrm{N} \mathrm{L}^{-1}$ ) were also substantially higher than those measured in the other ponds

$\left(\mathrm{NH}_{4}{ }^{+}=<0.002\right.$ to $0.029, \mathrm{NO}_{3}^{-}=<0.002$ to $\left.0.019 \mathrm{mg} \mathrm{N} \mathrm{L}^{-1}\right)$.

254 Gross primary production (GPP) rates ranged from $39 \mathrm{mg} \mathrm{O}_{2} \mathrm{~m}^{-2} \mathrm{~h}^{-1}$ to $247 \mathrm{mg} \mathrm{O}_{2} \mathrm{~m}^{-2} \mathrm{~h}^{-1}$. Hourly 255 respiration rates (R) were between $50 \mathrm{mg} \mathrm{O}_{2} \mathrm{~m}^{-2} \mathrm{~h}^{-1}$ and $252 \mathrm{mg} \mathrm{O}_{2} \mathrm{~m}^{-2} \mathrm{~h}^{-1}$. There were significant 256 differences in benthic GPP, NEP and R hourly rates among the study ponds (Kruskal Wallis, $\mathrm{p}=$ $2570.013,0.023$ and 0.021 , respectively). Pairwise comparisons showed that D1 had significantly higher 258 GPP than A1, A2 and B2. C1 and C2 also had significantly higher GPP than A1 and B2. B1 had 259 significantly higher benthic respiration than all of the other study ponds. All ponds were 260 heterotrophic, with GPP/R ratios well below one (0.12 to 0.53$)$ and these ratios did not differ significantly across the study ponds (Kruskal Wallis, $\mathrm{p}=0.053$ ).

There was a total of 16 macrophyte species found in the farm pond littoral zones with individual ponds having between 1 to 10 species present (Table 2, Appendix 1). The abundance of macrophytes (measured as total \% cover) ranged from 2 to $108 \%$. C1, D1 and D2 had significantly lower macrophyte cover than A1, B1, B2 and C2 (Kruskal Wallis, $\mathrm{p}=0.004$ ). The dominance of each structural type (emergent, floating and submerged) also differed across the waterbodies, resulting in the 8 study ponds encompassing a large range of habitat complexity. Photic depth and turbidity did not have a significant relationship with total macrophyte species richness (Spearman's rank coefficients 0.386 and -0.422 respectively) or macrophyte abundance (Spearman's rank coefficients

$271 \quad 0.476$ and -0.595 respectively).

\section{Littoral Zone Biodiversity}

274 Of the sixteen macrophyte species recorded in the study ponds, only four of these were introduced 275 species (Nymphaea caerulea, Callitriche stagnalis, Cabomba caroliniana and Urochloa mutica). The 276 most common plants (found in at least half of the ponds) were the native species Juncus usitatus,

277 Schoenoplectus mucronatus and Ludwigia pepliodes ssp. montevidensis and the introduced species 278 Urochloa mutica. There was a significant difference for both macrophyte species richness and 
diversity among the eight study ponds (Kruskal Wallis, $p=0.006$ and $p=0.005$, respectively). The

highest species richness recorded in the farm ponds was ten in pond B1 (Table 2). Pairwise comparisons showed that this pond contained significantly more macrophyte species than $\mathrm{C} 1, \mathrm{D} 1$ and D2 which contained only one or two different species. Pairwise comparisons also grouped the ponds into two separate groups based on their macrophyte diversity. A1, A2, B1, B2 and C2 were all more

284 diverse than C1, D1 and D2. During the sampling, it was also visibly noticeable that A1, A2, B1, B2 and C2 had higher \% littoral zone macrophyte cover (>45\%) while C1, D1 and D2 all had very low percentage cover $(<12 \%)$. These two distinct groupings of ponds are referred to as well vegetated and poorly vegetated in subsequent analyses which consider $\%$ macrophyte cover as being a measure of littoral zone habitat structure.

Fourteen invertebrate orders and forty-five families were found across the eight study ponds (Table 3; Appendix 1). Most families were representatives of the orders Hemiptera, Coleoptera, Odonata and Diptera. There was a significant difference among ponds when comparing both invertebrate family richness and family diversity (Kruskal Wallis, $p=0.004$ and $p=0.007$, respectively). B1 had the highest total family richness and average family richness (27 and 19.7 respectively) while D1 had the lowest total richness value of 15 and A2 had the lowest average family richness of 10.3. Pairwise comparisons (based on replicate data) showed that B1 had significantly greater invertebrate family taxonomic groups than D1, C1 and A2. Pairwise comparisons also showed that $\mathrm{C} 2$ and $\mathrm{A} 1$ were significantly more diverse than A2, D1 and B2. The number of aquatic invertebrate families occurring in the littoral zones of the study ponds was significantly related to the percentage macrophyte cover

300 (Spearman's rank coefficient 0.671, $\mathrm{p}<0.001$ ) (Figure 2a).

The community structure of invertebrates among the eight study ponds was significantly different

303 based on multivariate analysis of abundance data (ANOSIM, Global R $=0.951, p=0.001$; Figure 3a).

304 Invertebrate community structure was significantly different between ponds with poorly and well

305 vegetated littoral zones (ANOSIM, Global $\mathrm{R}=0.492, \mathrm{p}=0.001$; Figure $3 \mathrm{~b}$ ). SIMPER analysis

306 revealed that this grouping was due to the presence of two Chironomid subfamilies, chironominae and 
tanypodina, and the Corixididae family in poorly vegetated ponds and the Atyidae family in well

308 vegetated ponds. These four family groups cumulatively contributed $73 \%$ to the dissimilarity in

309 invertebrate community structure in the differently vegetated ponds.

311 The highest total number of taxa (macrophytes + invertebrates) was recorded at B1 (37 different taxa).

312 D1 supported the lowest total number of taxa, with only 18 different taxa recorded. Total species

313 richness did not exhibit significant relationships with pond age or area (Spearman's rank coefficients

3140.188 and -0.048 respectively) (Figures $2 b$ and $c$ ).

\section{Landowner knowledge and farm pond management}

317 Cattle have regular access (ranging from unrestricted to access one week/month) to all but one of the

318 study ponds (D2), which is permanently fenced due to its steep slopes. Two other ponds (B1 and A1)

319 have had riparian vegetation successfully planted around or near the pond. These are the only major 320 management strategies in place for any of the study ponds (Table 1).

Not surprisingly, all of the landowners recognised the importance of the farm ponds as reliable water sources, with this role being ranked as the most important factor (average rank of 9/10) to consider when making management decisions. Habitat and nature conservation were the next highest ranked factors (ranked 7 and 5 out of 10 respectively on average). Other factors such as financial and policy requirements were not ranked by any of the landowners as important when making management decisions regarding the ponds.

The landowners were able to correctly identify which of their ponds was most diverse, and also fairly accurately predicted how diverse their ponds were on a scale of fair to very good. For the three ponds with the lowest measured biodiversity $(\mathrm{C} 1, \mathrm{D} 1$ and $\mathrm{D} 2)$, the landowners correctly predicted that these

332 ponds only had 'fair' biodiversity. The three ponds that were predicted to have 'very good'

333 biodiversity were the three ponds for which the highest biodiversity was measured. There was a highly 
significant correlation between the biodiversity predicted by the landowners and the biodiversity measured in the ponds (Spearman correlation coefficient $=0.856 ; p=0.007)($ Figure 4$)$.

\section{Discussion}

\section{Farm ponds as aquatic habitat}

339 This case study clearly shows that farm ponds in the Stanley River catchment, South-East Queensland

340 can support native macrophytes and invertebrates. Our results are similar to findings from temporary

341 ponds located in grazed areas of Great Britain that support both rare and common macrophytes and

342 invertebrates (Nicolet and others 2004). Further, farm ponds in Japan have been shown to be

343 important habitats for rare aquatic plants and Odonates (Takasaki 1994 and Kadono 1998, as cited in

344 Maezono and Miyashita 2004). Together these studies and our results clearly demonstrate the

345 potential importance of managed waterbodies in nature conservation.

347 Although no rare or uncommon species were found in the farm ponds, many of the invertebrate

348 families sampled in the farm ponds have been recorded in nearby streams by the South-East

349 Queensland Environmental Health Monitoring Program (EHMP) in 2002/2003 (Table 3). Even

350 though the farm ponds would be assumed to support habitat conditions very different to streams,

351 highly variable rainfall in South-East Queensland results in many streams have very low or even no

352 flow during the dry season, resulting in dominance of pool environments (Smith and others 2001).

353 This could explain why many of the following orders had almost all of the same families recorded in

354 the farm ponds and the EHMP sites: Acarina, Hirudinea, Bivalvia, Decapoda, Ephemoptera,

355 Hemiptera, and Lepidoptera. The average family richness (number of families recorded at each site)

356 across all ten EHMP sites was 28 (ranging from 18 to 34 over the two sampling years) while the farm

357 ponds averaged 21 invertebrate families/pond (values between 15 and 27). Considering only three of

358 the farm ponds had any management strategies in place, these values are quite promising when

359 considering farm ponds as possible habitats for fauna. 
It is generally argued that aquatic richness and biodiversity are positively related to either the size of

362 the water body (MacArthur and Wilson 1967; Allen and others 1999; Hansson and others 2005) or its 363 habitat complexity (Zimmerman and Bierregaard 1986, as cited in Hazell and others 2001; Bunn and 364 Arthington 2002; Statzner and Moss 2004). The results from this study suggest that the presence and complexity of littoral zone macrophyte habitats within the study ponds was more important than area

366 in influencing aquatic invertebrate richness. This is supported by other studies that have found that

367 the presence of invertebrates in lentic aquatic systems is often closely linked with habitat complexity,

368 such as the presence of macrophytes (Timms 1980; Murkin and Ross 2000; Nicolet and others 2004).

369 Further tests of the role of pond size would require both a broader range in sizes and some control over 370 pond age as this can also influence the species richness of benthic invertebrates (Hansson and others 371 2005). Age was not significantly related to aquatic taxonomic richness in this study due to ponds like 372 B1, which was one of the youngest ponds, but supported the highest number of invertebrate families.

374 The presence of aquatic vegetation also had an effect on the composition of the invertebrate

375 communities. Ponds with poorly vegetated littoral zones had communities that were dominated by

376 Corixidae and two Chironomid subfamilies (chironominae and tanypodina), which are common in 377 artificial freshwater habitats such as farm and aquaculture ponds (Timms 1980; Ingram and others 378 1997). The presence of Atyidae also contributed to the difference between the invertebrate 379 communities of the well vegetated and poorly vegetated ponds. These are detritus feeders which are 380 commonly found in the littoral environments of farm ponds and aquaculture ponds (Ingram and others 381 1997). Although there was a difference in the community compositions between ponds with heavily 382 vegetated ponds and those with bare littoral zones, most of families present in both types were 383 common and tolerant organisms.

385 The factors responsible for the establishment of macrophytes in farm ponds are not well known

386 (Casanova and others 1997), but the environmental conditions needed to support their growth have 387 been studied in natural lakes and wetlands (Perkins and Underwood 2002; Herb and Stefan 2003, 388 Hietala and others 2004). These include relatively clear water and adequate nutrient concentrations; 
although if the threshold nutrient levels are exceeded, high phytoplankton and epiphyte density can shade out macrophytes (Scheffer and others 1993). Inorganic/sediment turbidity can also serve to

391 limit light penetration (Scheffer and others 1993; Declerck and others 2006). Although high turbidity and associated shallow photic depths are known to influence macrophyte growth due to limitation of light for photosynthesis, there was no significant relationship found between turbidity and macrophyte

394 richness or abundance in this study. This may be due to all but one pond (C1) having photic depths 395 greater than one metre (which was generally the greatest depth recorded in the littoral zones of any of 396 the ponds), thereby not limiting plant growth in these areas.

398 The abundance and richness of aquatic vegetation in farm ponds is also likely to be affected by the pond's age, stock access and substrate type (Timms 1980; Hansson and others 2005; Declerck and others 2006). Older ponds are likely to have more complex littoral zone habitats, although this was

401 not observed in this study, as one of the newest ponds supported the most diverse macrophyte

402 community (B1). Stock access was only restricted to one of the study ponds (D2), which actually had one of the least rich macrophyte communities. These factors alone could not explain the absence of complex macrophyte habitats in some of the study ponds. It is likely that a complex interaction of these factors affects the establishment and survival of macrophytes in farm pond littoral zones (Herb and Stefan 2003), and looking across the 8 study ponds, these interactions were not able to be resolved

407 definitively. However, in terms of suggestions for management practices, it is generally recognised 408 that likelihood of macrophyte occurrence in farm ponds can be enhanced by managing stock access 409 and reducing nutrient inputs (Declerck and others 2006). Direct planting of macrophytes in the littoral 410 zone may also be useful method if the water quality of the ponds are adequate to support them 411 (Frankenberg 1998).

\section{Water quality}

414 Water quality can exert a strong influence on habitats, ecosystem functioning and the biota of aquatic 415 systems (Platt and Corrick 1994; Brainwood and others 2004; EHMP 2004). Overall, the physical and 416 chemical characteristics of the water in the study ponds are of better quality than the limited number of 
418 4). The study ponds should provide better submerged macrophyte habitat than the three farm ponds in 419 the Central NSW Tablelands studied by Brainwood and others (2004) which had higher levels of 420 nutrients, turbidity and chlorophyll $a$. The ranges of values across the eight study ponds for 421 temperature, dissolved oxygen and $\mathrm{pH}$ were smaller than those observed in other farm ponds studied 422 in Australia. This is likely due to the smaller sample size of this study when compared to Hazell and 423 others (2001) and the fact that the study ponds were only sampled once compared to Brainwood and 424 others (2004) in which sampling was conducted monthly over a year.

426 Since all of the properties were in agricultural areas, and the properties themselves all had cattle, turbidity and nutrient levels were expected to be high (Timms 1980; Garnier and others 2000). The water clarity in the study ponds was quite surprising, as stock usage is likely to increase turbidity due to trampling. Overall, the ponds had fairly similar nutrient concentrations except D1, which had high levels of dissolved forms of nitrogen and $\mathrm{C} 1$ which had the highest TP concentration. Both of these ponds have unrestricted stock access, low macrophyte cover and limited riparian zone vegetation (only short grass and bare ground), which may explain these high nutrient levels since there are no buffers in place (Declerck and others 2006). However, even these high concentrations are low compared the findings of Brainwood and others (2004) for three ponds surrounded by more intensive land use including pasture, a pet food production factory, and several smaller industrial plants and a grain store.

GPP rates in this study are high enough to suggest benthic algae could serve as an important food

438 source. However, the GPP/R ratios in all of the farm ponds were well below 1, suggesting that algal 439 production alone is not sufficient to fuel the observed levels of respiration (Hanson and others 2003). 440 This supports statements made by Robinson and others (2000) who state that the decomposition of 441 macrophyte detritus may primarily fuel food webs in wetland environments. However, several studies 442 using stable isotopes have shown that even in littoral zones dominated by macropytes, attached algae 443 can still represent the major carbon source in the aquatic food web (Hecky and Hesslein 1995;

444 Hadwen and Bunn 2005). Additional research characterising both potential food sources such as 
445 benthic production, and foodweb structure in farm pond littoral zones over time would provide a

446 clearer picture how these ecosystems operate.

\section{Managing farm ponds as habitats}

449 In areas of cattle grazing, managing stock access to farm ponds should increase aquatic habitat value.

450 Cattle utilising farm ponds are likely to degrade the quality of littoral habitats due to their weight,

451 frequent return to the same site to drink, and by grazing on emergent plants (Lloyd and others 1998).

452 They also cause erosion by trampling and removing palatable riparian plant species, and their excreta

453 can cause nutrient enrichment (Platt and Corrick 1994; Frankenberg 1998; Declerck and others 2006).

454 Fencing off ponds to restrict cattle access is one suitable management strategy. Vegetated buffer

455 zones near the ponds are also beneficial to water bodies, protecting the system from pollutants as well 456 as providing terrestrial habitat (Platt and Corrick 1994; Nicolet and others 2004; Declerck and others 457 2006). Appropriate management may minimise impacts to water quality and macrophytes and ensure 458 that farm ponds function as a suitable aquatic habitats (Brainwood and others 2004).

460 Even though the landowners in this study had a good understanding of the biodiversity of their ponds 461 and rated conservation as a high factor in determining decisions regarding on-farm management, only 462 three of the eight study ponds had management strategies in place. Only two of these ponds have actually had management strategies implemented to increase biodiversity (A1 and B1). Both of these

464 landowners have strong conservation values as shown by the fact that they both ranked habitat and/or 465 nature conservation factors "ten" (out of ten). Landowner B stated that "restoring (the) environment to 466 its original condition and to see the effect of riparian restoration on the health of the pond" is 467 important, and landowner A recognised the "need for more wetland habitats".

469 Results from this study suggest that strong conservation values may not necessarily lead to the 470 implementation of farm pond management strategies. Even though landowner $\mathrm{C}$ places high value on 471 habitat (ranked nine out of ten), he did not recognise farm ponds as important habitats or the potential 472 influence of management strategies could have on them. 

water is not clear].....They eventually get silted up and then plants can grow in them."

475 This landowner has instead concentrated on restoration efforts along the creek that runs through his property. Perhaps increasing this landowners awareness of the potential of farm ponds to provide habitat would result in the implementation of management strategies on these waterbodies, as Tenge and others (2004) found that increased awareness about soil erosion positively influenced landowners adoption of conservation measures.

Findings in this study also suggest that factors other than conservation values, such as livestock care, can lead to management decisions that may inadvertently promote farm pond biodiversity. Landowner D did not rank habitat or nature conservation as important factors influencing management decisions for farm ponds and placed fencing around D2 due to its steep slopes that may injure his cattle.

Overall, the results from this case study suggest that while farmers with pro-conservation values may introduce farm pond management strategies, such as tree-planting in the riparian zone, other factors such as livestock care will also influence management decisions which may inadvertently improve farm pond biodiversity. Increasing landowners' awareness of the potential of these artificial systems to provide habitat for many native aquatic macrophytes and invertebrates may also increase the 491 likelihood of farm pond management strategies being put in place (Tenge and others 2004). Potential

492 limitations of the study were the small sample size of the survey, as well as the fact that the 493 participants in this case study were all environmentally aware, having connections with the local 494 Landcare group which aims to increase awareness and knowledge of landowners with regard to the 495 sustainable resource management (Curtis and others 2000). It is therefore important to focus more research on a range of farmers' attitudes towards conservation to determine how to encourage

497 landowners who do not have pro-conservation values to uptake farm pond management strategies to 498 increase habitat values (Beedell and Rehman 1999). Pyrovetsi and Daoutopoulos (1997) recognise 499 that providing landowners with relevant information and education about on-farm conservation is a 
key strategy to help landowners form a more pro-conservation attitude and encourage them to adopt

501 pro-environmental on-farm management strategies.

\section{Conclusion}

504 Farm ponds are able to support a wide range of native aquatic flora and fauna. The invertebrate communities recorded in these artificial habitats are comparable to surrounding natural streams,

506 although somewhat less rich in at the family level. The potential habitat value of these ponds may be even greater, as most of the study ponds currently have no management strategies in place to enhance biodiversity. The close relationship observed between macrophyte cover and invertebrates suggest management strategies that result in establishment and maintenance of littoral macrophytes will improve habitat value. Landowners should be informed on the potential importance of farm ponds as habitats for native flora and fauna. This increased knowledge may lead to more landowners

512 implementing farm pond management strategies. Overall, with natural wetlands diminishing in the

513 landscape, and farm ponds proliferating due to the need for reliable water, it seems that these artificial

514 habitats can provide an important alternative habitat for many native floral and faunal species.

To best determine how to manage these artificial systems for increased biodiversity, we suggest a larger study should be undertaken to uncover the cause and effect of management strategies on pond littoral zone habitat and biota. This case study gains its strength by combining social science techniques with ecological research. We recommend that future studies also attempt to combine both sciences to optimise proposed management strategies by ensuring that they are practical and are designed to achieve landowners goals as well as biodiversity goals.

524 We are indebted to all of the landowners who allowed us access to their properties and provided 525 additional information about the management of their farm ponds. Thanks also to the Ecosystem 526 Health Monitoring Program (EHMP) of the Moreton Bay Waterways and Catchments Partnership for 527 making data available to be used in this paper. We also thank Fran Sheldon for her advice in sampling 
528 techniques and data analysis; Dan Wruck for analysing our nutrient samples; Wade Hadwen for

529 providing helpful comments to help develop this manuscript; and the many field volunteers who

530 helped to collect this data. This project was funded by the Griffith School of Environment and the

531 Australian Rivers Institute, Griffith University.

532 
534 Allen, A.P., T.R. Whittier, P.R. Kaufmann, D.P. Larsen, R.J. O'Connor, R.M. Hughes, R.S.

535 Stemberger, S.S. Dixit, R.O. Brinkhurst, A.T. Herlihy and S.G. Paulsen. 1999. Concordance of

536 taxonomic richness patterns across multiple assemblages in lakes of the northeastern United States.

537 Canadian Journal of Fisheries and Aquatic Sciences 56: 739-747.

538

539 Altieri, M.A. 1999. The ecological role of biodiversity in agroecosystems. Agriculture Ecosystems and

540 Environment 74:19-31.

Babbie, E. 1990. Survey Research Methods. Wadsworth Publishing Company, California.

544 Beedell, J.D.C. and T. Rehman. 1999. Explaining farmers' conservation behaviour: Why do farmers 545 behave the way they do? Journal of Environmental Management 57: 165-176.

Bentham, C.G.M., M.J. 1982. Social surveys. In: R. Haynes (ed.) Environmental Science Methods,

BOM. 2005a. Average daily sunshine hours - January to December: Brisbane, Commonwealth Bureau of Meteorology. (online) Available from: http://www.bom.gov.au/cgibin/climate/cgi_bin_scripts/idl_sunh_graphs/sunh_script.cgi?40214 (Accessed 27 February 2005). 
Brock, M.A., R.G.B. Smith and P.J. Jarman. 1999. Drain it, dam it: alteration of water regime in

562 shallow wetlands on the New England Tableland of New South Wales, Australia. Wetlands Ecology

563 and Management 7: 37-46.

564

565 Bunn, S.E. and A.H. Arthington. 2002. Basic principles and ecological consequences of altered flow

566 regimes for aquatic biodiversity. Environmental Management 30: 492-507.

567

568 Casanova, M.T., A. Douglas-Hill, M.A. Brock, M. Muschal and M. Bales. 1997. Farm Ponds in New

569 South Wales, Australia: relationship between macrophyte and phytoplankton abundances. Marine and

$570 \quad$ Freshwater Research 48: 353-360.

571

572 Cummins, K.W. and R.W. Merritt. 2001. Application of Invertebrate Functional Groups to Wetland

573 Ecosystem Function and Biomonitoring. In: R.B. Rader, D.P. Batzer and S.A. Wissinger (eds.)

574 Bioassessment and Management of North American Freshwater Wetlands, Wiley, New York.

575

576 Curtis, A., Nouhuys, M.V., Robinson, W. and Mackay, J. 2000. Exploring Landcare effectiveness

577 using organisational theory. Australian Geographer 31: 349-366.

578

579 Declerck, S., T. De Bie, D. Ercken, H. Hampel, S. Schrijvers, J. Van Wichelen, V. Gillard, R.

580 Mandiki, B. Losson, D. Bauwens, S. Keijers, W. Vyverman, B. Goddeeris, L. De meester, L.

581 Brendonck, and K. Martens. 2006. Ecological characteristics of small farmland ponds: Associations

582 with land use practices at multiple spatial scales. Biological Conservation 131:523-532.

584 Denzin, H.K. and Y.S. Lincoln. 2003. The Discipline and Practice of Qualitative Research. Sage

585 Publishers, Thousand Oaks, California, London.

EHMP. 2004. Ecosystem Health Monitoring Program 2002-2003 Annual Technical Report, Moreton

Bay Waterways and Catchments Partnership, Brisbane. 
590 Benthic metabolism as an indicator of stream ecosystem health. Hydrobiologia 572: 71-80.

Fellows, C.S., Valett, H.M. and Dahm, C.N. 2001. Whole-stream metabolism in two montane streams:

Frankenberg, J. 1998. Enhancing Farm Dams. In: F. Stelling (ed.) From Little Things Big Things

Grow..... Revegetation Guide for the Riverina Highlands, Murray Catchment Management Committee, Albury, NSW.

Garnier, J., G. Billen, N. Sanchez and B. Leporcq. 2000. Ecological functioning of the Marne reservoir (upper Seine basin, France). Regulated Rivers-Research and Management 16: 51-71.

601

Goldsborough, G. 2001. Sampling algae in wetlands. In: R.B. Rader, D.P. Batzer \& S.A. Wissinger 603 (eds.) Bioassessment and Management of North American Freshwater Wetlands, Wiley, New York.

604

Greenberg, A.E., Clesceri, L.S. and Eaton, A.D. (eds). 1992. Standard methods for the examination of

606 water and wastewater, $18^{\text {th }}$ edition. American Public Health Association, American Water Works Association and Water Environment Foundation, Washington.

608

609 Hadwen, W.L. and Bunn, S.E. 2005. Food web responses to low-level nutrient and ${ }^{15} \mathrm{~N}$-tracer

610 additions in the littoral zone of an oligotrophic dune lake. Limnology and Oceanography 50: 1096-

6111105.

612

613 Hanson, P.C., D.L. Bade, S.R. Carpenter and T.K. Kratz. 2003. Lake metabolism: Relationships with 614 dissolved organic carbon and phosphorus. Limnology and Oceanography 48: 1112-1119. 
616 Hansson, L., C. Bronmark, P.A. Nilsson and K. Abjornsson. 2005. Conflicting demands on wetland

617 ecosystem services: nutrient retention, biodiversity or both? Freshwater Biology 50: 705-714.

618

619 Hazell, D., R. Cunnningham, D. Lindenmayer, B. Mackey and W. Osborne. 2001. Use of farm dams

620 as frog habitat in an Australian agricultural landscape: factors affecting species richness and

621 distribution. Biological Conservation 102: 155-169.

622

623 Hazell, D., J.M. Hero, D. Lindenmayer and R. Cunningham. 2004. A comparison of constructed and 624 natural habitat for frog conservation in an Australian agricultural landscape. Biological Conservation 625 119: 61-71.

626

627 Hecky, R.E. and Hesslein, R.H. 1995. Contributions of benthic algae to lake food webs as revealed by 628 stable isotope analysis. Journal of the North American Benthological Society 14 (4): 631-653.

630 Herb, W. R., and H. G. Stefan. 2003. Integral growth of submersed macrophytes in varying light 631 regimes. Ecological Modelling 168:77-100.

632

633 Hietala, J., K. Vakkilainen, and T. Kairesalo. 2004. Community resistance and change to nutrient 634 enrichment and fish manipulation in a vegetated lake littoral. Freshwater Biology 49:1525-1537.

635

636 Ingram, B.A., J.H. Hawking and R.J. Shiel. 1997. Aquatic Life in Freshwater Ponds: A Guide to the 637 Identification and Ecology of Life in Aquaculture Ponds and Farm Dams in South Eastern Australia. 638 Co-operative Research Centre for Freshwater Ecology, Albury, NSW.

639

640 Kadono, Y. 1998. Aquatic plants community in farm pond. In: Y. Ezaki and T. Tanaka (eds)

641 Preservation of Waterside Environment: from viewpoint of Bio-Community. Asakura Shoten, Tokyo, 642 Japan (in Japanese).

643 
645 software for assessing the costs and benefits of on-farm water storage based production systems. 646 Agricultural Systems 76: 19-38.

647

648 Lloyd, S.D., P. Bishop and I. Reinfelds. 1998. Shoreline erosion: a cautionary note in using small farm 649 dams to determine catchment erosion rates. Earth Surface Processes and Landforms 23: 905-912.

650

Loi, J.K. and D.T. Malcolm. 1998. Land Resource Assessment SEQ 2001 Report 6: Soils and Land

Suitability The Kilcoy-Woodford Area, Department of Natural Resources, Brisbane.

653

654 MacArthur, R.H. and E.O. Wilson. 1967. The Theory of Island Biogeography. Priceton University 655 Press, Princeton.

656

Maezono, Y. and T. Miyashita. 2004. Impact of exotic fish removal on native communities in farm 658 ponds. Ecological Research 19: 263-267.

659

660 Murkin, H. R., and L. C. M. Ross. 2000. Invertebrates in Prairie Wetlands. In: H. R. Murkin, A. G.

661 Van Der Valk, and W. R. Clark, (eds.). Prairie Wetland Ecology: The Contribution of the Marsh 662 Ecology Research Program. Iowa State University Press, Ames, Iowa.

663

664 Nichols, P. 1991. Social Survey Methods: A Fieldguide for Development Workers. Oxfam, Oxford. 665

666 Nicolet, P., J. Biggs, G. Fox, M.J. Hodson, C. Reynolds, M. Whitfield and P. Williams. 2004. The 667 wetland plant and macroinvertebrate assemblages of temporary ponds in England and Wales.

668 Biological Conservation 120: 265-282.

669

670 Perkins, R. G., and G. J. C. Underwood. 2002. Partial recovery of a eutrophic reservoir through

671 managed phosphorus limitation and unmanaged macrophyte growth. Hydrobiologia 481:75-87. 
673 Platt, S. and A. Corrick. 1994. Management of shallow freshwater wetlands for wildlife. Trees and 674 Natural Resources, September 2004; 12-18.

675

676 Pyrovetsi, M. and Daoutopoulos, G. 1997. Contrasts in conservation attitudes and agricultural

677 practices between farmers operating in wetlands and a plain in Macedonia, Greece. Environmental 678 Conservation 24: 76-82.

679

680 QNRM. 2003. Preliminary Assessment of Overland Flow Significance in the Moreton Region,

681 Department of Natural Resources and Mines, Queensland Government.

682

683 Rickson, R., P. Saffigna, F. Vanclay and G. McTainsh. 1987. Social bases of farmers' responses to

684 land degradation. In: A. Chisholm and R. Dumsday (eds.) Land Degradation: Problems and Policies, 685 Cambridge University Press, Cambridge.

686

687

Reidsma, P., T. Tekelenburg, M. van den Berg, and R. Alkemade. 2006. Impacts of land-use change 688 on biodiversity: An assessment of agricultural biodiversity in the European Union. Agriculture Ecosystems and Environment 114:86-102.

690

691 Robinson, G.G.C., S.E. Gurney and L.G. Goldsborough. 2000. Algae in Prairie Wetlands. In: H.R.

692 Murkin, A.G. Van Der Valk and W.R. Clark (eds.) Prairie Wetland Ecology. Iowa State University 693 Press, Ames, Iowa.

694

Robson, B. J., and C. J. Clay. 2005. Local and regional macroinvertebrate diversity in the wetlands of

696 a cleared agricultural landscape in south-western Victoria, Australia. Aquatic Conservation: Marine 697 and Freshwater Ecosystems 15:403-414.

698 
Scheffer, M., S. H. Hosper, M.-L. Meijer, B. Moss, and E. Jeppesen. 1993. Alternative equilibria in

700 shallow lakes. Trends in Ecology and Evolution 8:275-279.

701

702

Schuman, H. and S. Presser. 1981. Questions and Answers in Attitude Surveys : Experiments on

703

Question Form, Wording, and Context. Academic Press, New York.

704

705

Smith, M.J., Bunn, S.E., Storey, A.W., Harch, B.D. and Redfern, F.M. 2001. Process undertaken to

706

develop and EHMP for rivers and streams in South East Queensland. In: M.J. Smith and A.W. Storey

707

(eds.) Design and Implementation of Baseline Monitoring (DIBM3): Developing an ecosystem health

708

monitoring program for rivers and streams in Southeast Queensland. Centre for Catchment and In-

709

Stream Research (CCISR), Griffith University and South East Queensland Regional Water Quality

710

Management Stragegy (SEQRWQMS), Brisbane.

711

712

Statzner, B. and B. Moss. 2004. Linking ecological function, biodiversity and habitat: a mini-review

713

focusing on older ecological literature. Basic and Applied Ecology 5: 97-106.

714

715

Sudman, S. and N.M. Bradburn. 1974. Response Effects in Surveys: A Review and Synthesis. Aldine

Publishers, Chicago.

717

Takasaki, Y. 1994. Odonata of irrigation pond. In The research group of natural irrigation pond (eds).

Introduction to Natural History of Irrigation Pond. Gogo Shuppan, Tokyo, Japan (in Japanese)

720

Tenge, A.J., De Graaff, J. and Hella, J.P. 2004. Social and economical factors affecting the adoption of

soil and water conservation in West Usambara Highlands, Tanzania. Land Degradation and

Development 15:99-114. 
728 Tress, B. 2002. Application of Landscape Ecology. In: O. Bastian and U. Steinhardt (eds.)

729 Development and Perspectives of Landscape Ecology, Kluwer Academic Publishers, Dordrecht, The

730 Netherlands.

731

732 Tscharntke, T., A. M. Klein, A. Kruess, I. Steffan-Dewenter, and C. Thies. 2005. Landscape

733 perspectives on agricultural intensification and biodiversity - ecosystem service management. Ecology

734 Letters 8:857-874.

735

736 Waterways. 2002. Stanley Catchment, Healthy Waterways. (online) Available from:

737 http://www.healthywaterways.org/PAGE120417PM5Y31FI.html (Accessed 10 August 2004).

738

739 Wetzel, R.G. and G.E. Likens. 1991. Limnological Analyses, $2^{\text {nd }}$ edition. Springer-Verlag, New York.

740

741 Williams, P., M. Whitfield, J. Biggs, S. Bray, G. Fox, P. Nicolet, and D. Sear. 2003. Comparative

742 biodiversity of rivers, streams, ditches and ponds in an agricultural landscape in Southern England.

743 Biological Conservation 115:329-341.

744

745 Zimmerman, B.L. and R.O. Bierregaard. 1986. Relevance of the equilibrium theory of island

746 biogeography and species-area relations to conservation with a case from Amazonia. Journal of

747 Biogeography 13: 133-143.

748 
750 Appendix 1: List of all macrophyte and invertebrate taxa recorded across all 8 ponds. * $=$

751 subfamily

\begin{tabular}{|c|c|c|c|c|}
\hline Class & Order & Family & Genus/Species & Location (Pond ID) \\
\hline \multicolumn{5}{|c|}{ CHAROPHYCEAE } \\
\hline & Charales & Characeae & Charophyte sp. & B1, B2 \\
\hline \multicolumn{5}{|c|}{ PTEROPSIDA } \\
\hline & Marsileales & Azollaceae & Azolla sp. & $\mathrm{A} 1, \mathrm{~B} 1, \mathrm{C} 2$ \\
\hline \multicolumn{5}{|c|}{ LILIOPSIDA } \\
\hline & Arales & Lemnaceae & Wolffia sp. & B1, B2 \\
\hline & Commelinales & Philydraceae & Philydrum languginosum & $\mathrm{A} 1, \mathrm{~A} 2$ \\
\hline & Hydrocharitales & Hydrocharitaceae & Ottelia ovalifolia & B1, B2, D1 \\
\hline & Typhales & Typhaceae & Typha orientalis & $\mathrm{A} 1, \mathrm{~B} 1, \mathrm{~B} 2$ \\
\hline & Cyperales & Cyperaceae & Eleocharis acuta & $\mathrm{C} 2$ \\
\hline & & & Schoenoplectus mucronatus & $\mathrm{A} 1, \mathrm{~A} 2, \mathrm{~B} 1, \mathrm{C} 2$ \\
\hline & & & Cyperus difformis & $\mathrm{A} 1$ \\
\hline & & Gramineae & Urochloa mutica & $\mathrm{B} 1, \mathrm{~B} 2, \mathrm{C} 1, \mathrm{C} 2, \mathrm{D} 2$ \\
\hline & Juncales & Juncaceae & Juncus usitatus & $\mathrm{A} 2, \mathrm{~B} 1, \mathrm{~B} 2, \mathrm{C} 1$ \\
\hline \multicolumn{5}{|c|}{ MAGNOLIOPSIDA } \\
\hline & Asterales & Menyanthaceae & Nymphoides indica & $\mathrm{C} 2$ \\
\hline & Lamiales & Callitrichaceae & Callitriche stagnalis & $\mathrm{B} 1, \mathrm{~B} 2$ \\
\hline & Myrtales & Onagraceae & $\begin{array}{l}\text { Ludwigia peploides ssp. } \\
\text { montevidensis }\end{array}$ & $\mathrm{A} 1, \mathrm{~B} 1, \mathrm{~B} 2, \mathrm{C} 2$ \\
\hline & Nymphaeales & Cabombaceae & Cabomba caroliniana & $\mathrm{A} 2$ \\
\hline & & Nymphaeaceae & Nymphaea caerulea & $\mathrm{A} 1$ \\
\hline
\end{tabular}

\section{HIRUNDINEA}

Hirudinidae

$\mathrm{B} 1, \mathrm{~B} 2, \mathrm{C} 1, \mathrm{C} 2, \mathrm{D} 1, \mathrm{D} 2$

MOLLUSCA

$\begin{array}{ll}\text { Bivalvia } & \text { Sphaeriidae } \\ \text { Gastropoda } & \text { Lymnaeidae } \\ & \text { Physidae }\end{array}$

\section{CRUSTACEA}

ARACHNIDA

$\begin{array}{ll}\text { Cladocera } & \text { Daphniidae (in part) } \\ \text { Decapoda } & \text { Parastacidae } \\ & \text { Atyidae } \\ & \text { Atyidae }\end{array}$

Austropeplea sp.
Physa acuta
unknown

B1

$\mathrm{B} 1, \mathrm{~B} 2, \mathrm{C} 2, \mathrm{D} 2$

B1, C2, D1, D2

A1, D1

B1, C1

Cherax sp.

$\mathrm{A} 1, \mathrm{~A} 2$

Caridina mccullochi

$\mathrm{A} 2, \mathrm{C} 2$

Parataya australiensis

$\mathrm{B} 1, \mathrm{~B} 2$

Acariformes Acarina

B1, C1, C2

COLLEMBOLA

INSECTA

Collembola Isotomidae

A1

$\begin{array}{ll}\text { Ephemeroptera } & \begin{array}{l}\text { Baetidae } \\ \text { Caenidae } \\ \text { Odonata }\end{array} \\ & \text { Aeshnidae } \\ & \begin{array}{l}\text { Coenagrionidae } \\ \text { Corduliidae } \\ \text { Hemicorduliidae } \\ \text { Libellulidae }\end{array}\end{array}$

Tasmanocoenis sp.

A1, A2, B1, B2

B1, B2, C1

$\mathrm{A} 1, \mathrm{~A} 2, \mathrm{~B} 1, \mathrm{~B} 2, \mathrm{D} 1, \mathrm{D} 2$

$\mathrm{A} 1, \mathrm{~A} 2, \mathrm{~B} 1, \mathrm{~B} 2, \mathrm{C} 1, \mathrm{C} 2, \mathrm{D} 1$, D2

Hemicorduliidae

D1

Nannophya sp.

A1, A2, B1, B2, D2

$\mathrm{A} 1, \mathrm{~B} 1, \mathrm{~B} 2, \mathrm{C} 1, \mathrm{C} 2, \mathrm{D} 2$ 


\begin{tabular}{|c|c|c|c|}
\hline & Lindeniidae & & B1 \\
\hline \multirow[t]{12}{*}{ Hemiptera } & Belostomatidae & & $\mathrm{A} 1, \mathrm{~B} 1, \mathrm{C} 2, \mathrm{D} 2$ \\
\hline & Corixidae & Agroptoerixa & $\mathrm{B} 1, \mathrm{~B} 2, \mathrm{C} 1, \mathrm{C} 2, \mathrm{D} 1, \mathrm{D} 2$ \\
\hline & Corixidae & Micronecta & $\mathrm{A} 2, \mathrm{~B} 1, \mathrm{~B} 2, \mathrm{C} 1, \mathrm{D} 1$ \\
\hline & Gerridae & & $\mathrm{A} 2$ \\
\hline & Hebridae & & $\mathrm{A} 1, \mathrm{~B} 1, \mathrm{~B} 2$ \\
\hline & Mesoveliidae & Mesovelia sp. & $\mathrm{A} 1, \mathrm{~A} 2, \mathrm{~B} 2, \mathrm{C} 2$ \\
\hline & Naucoridae & & $\mathrm{A} 1, \mathrm{~A} 2, \mathrm{~B} 1, \mathrm{C} 2$ \\
\hline & Nepidae & subfamily: Ranatrinae & $\mathrm{A} 2, \mathrm{C} 2$ \\
\hline & & Anisops sp. & $\mathrm{A} 1, \mathrm{~A} 2, \mathrm{~B} 1, \mathrm{~B} 2, \mathrm{C} 1, \mathrm{C} 2, \mathrm{D} 1$, \\
\hline & Notonectidae & & D2 \\
\hline & Pleidae & Paraplea sp. & $\mathrm{A} 1, \mathrm{~B} 1, \mathrm{~B} 2, \mathrm{C} 2$ \\
\hline & Veliidae & & B2 \\
\hline \multirow[t]{20}{*}{ Coleoptera } & Dytiscidae & Antiporus & A1 \\
\hline & Dytiscidae & Bidessodes & $\mathrm{C} 2$ \\
\hline & Dytiscidae & Cybister & $\mathrm{D} 1, \mathrm{D} 2$ \\
\hline & Dytiscidae & Eretes & $\mathrm{B} 1, \mathrm{D} 2$ \\
\hline & Dytiscidae & Hydacticus & $\mathrm{C} 2$ \\
\hline & Dytiscidae & Hyphydrus & $\mathrm{A} 1, \mathrm{~A} 2, \mathrm{~B} 1, \mathrm{~B} 2, \mathrm{C} 1, \mathrm{D} 2$ \\
\hline & Dytiscidae & Laccophilus & $\mathrm{B} 1, \mathrm{C} 2, \mathrm{D} 1, \mathrm{D} 2$ \\
\hline & Dytiscidae & larvae & $\mathrm{A} 1, \mathrm{~A} 2, \mathrm{~B} 1, \mathrm{~B} 2, \mathrm{C} 1, \mathrm{C} 2$, \\
\hline & Dytiscidae & Necterosoma & $\mathrm{A} 2, \mathrm{~B} 1, \mathrm{~B} 2, \mathrm{C} 1, \mathrm{C} 2$ \\
\hline & Dytiscidae & unknown & $\mathrm{A} 1, \mathrm{C} 2$ \\
\hline & Gyrinidae & adult & $\mathrm{A} 2, \mathrm{~B} 1, \mathrm{D} 2$ \\
\hline & Gyrinidae & larvae & $\mathrm{C} 1$ \\
\hline & Haliplidae & Haplilus sp. & B1 \\
\hline & Hydraenidae & Hydraena & $\mathrm{A} 1, \mathrm{~B} 1, \mathrm{~B} 2, \mathrm{C} 1, \mathrm{C} 2, \mathrm{D} 2$ \\
\hline & Hydrophilidae & adult & $\mathrm{A} 2, \mathrm{C} 2$ \\
\hline & Hydrophilidae & Berosus sp. larvae & $\mathrm{B} 1, \mathrm{C} 1, \mathrm{D} 1, \mathrm{D} 2$ \\
\hline & Hydrophilidae & Subfamily Hydrohpilinae & $\mathrm{A} 1, \mathrm{~A} 2, \mathrm{C} 1, \mathrm{C} 2, \mathrm{D} 2$ \\
\hline & Hygrobiidae & & $\mathrm{A} 2, \mathrm{~B} 2, \mathrm{C} 2$ \\
\hline & Psephenidae & Sclerocyphon sp. & B2 \\
\hline & Scirtidae & larvae & $\mathrm{A} 1, \mathrm{~B} 2, \mathrm{C} 2, \mathrm{D} 2$ \\
\hline \multirow[t]{8}{*}{ Diptera } & Ceratopogonidae & & $\mathrm{A} 1, \mathrm{~A} 2, \mathrm{C} 1, \mathrm{C} 2, \mathrm{D} 1, \mathrm{D} 2$ \\
\hline & Chironominae * & & D2 \\
\hline & Culicidae & & $\mathrm{A} 1, \mathrm{C} 2$ \\
\hline & Ephydridae & & D2 \\
\hline & Stratiomyidae & & A1 \\
\hline & $\begin{array}{l}\text { Tanypodinae } * \\
\text { unknown diptera }\end{array}$ & & $\begin{array}{l}\mathrm{A} 1, \mathrm{~A} 2, \mathrm{~B} 1, \mathrm{~B} 2, \mathrm{C} 1, \mathrm{C} 2, \mathrm{D} 1, \\
\mathrm{D} 2\end{array}$ \\
\hline & larvae & & A1, D1 \\
\hline & & & $\mathrm{A} 1, \mathrm{~A} 2, \mathrm{~B} 1, \mathrm{~B} 2, \mathrm{C} 1, \mathrm{C} 2, \mathrm{D} 1$, \\
\hline Trichoptera & Leptoceridae & & D2 \\
\hline Lepidoptera & Pyralidae & & A1 \\
\hline
\end{tabular}




\section{Figure captions}

754 Figure 1: Location of the study sites, Stanley River catchment, South-East Queensland. Circles

755 represent the locations of the towns in which the four properties (A, B, C and D) are located. Two

756 ponds (1 and 2) were sampled from each property.

758 Figure 2: Relationship between taxonomic richness and farm pond morphological and historical

759 characteristics. (a) Replicate values of invertebrate family richness and littoral zone habitat

760 complexity (measured as total macrophyte \% cover). Total taxonomic richness (invertebrate +

761 macrophyte) with (b) age and (c) pond area for each study pond.

762

763 Figure 3: MDS ordination of the invertebrate communities (abundance data) for all eight ponds. Each

764 point is one of three replicate samples from the littoral zones in each pond. Symbols indicate samples

765 from (a) all eight ponds separately and (b) ponds grouped based on vegetation status. Stress $=0.18$.

766

767 Figure 4: Relationship between total biodiversity predicted by landowners (as ranked from 1 to 4;

768 "fair" to "very good") and the measured total number of taxa in the ponds (macrophytes +

769 invertebrates). Different landowners are represented as: Landowner $A=\bullet$, Landowner $B=\square$,

770 Landowner $\mathrm{C}=\boldsymbol{\Delta}$, Landowner $\mathrm{D}=\mathrm{O}$ 


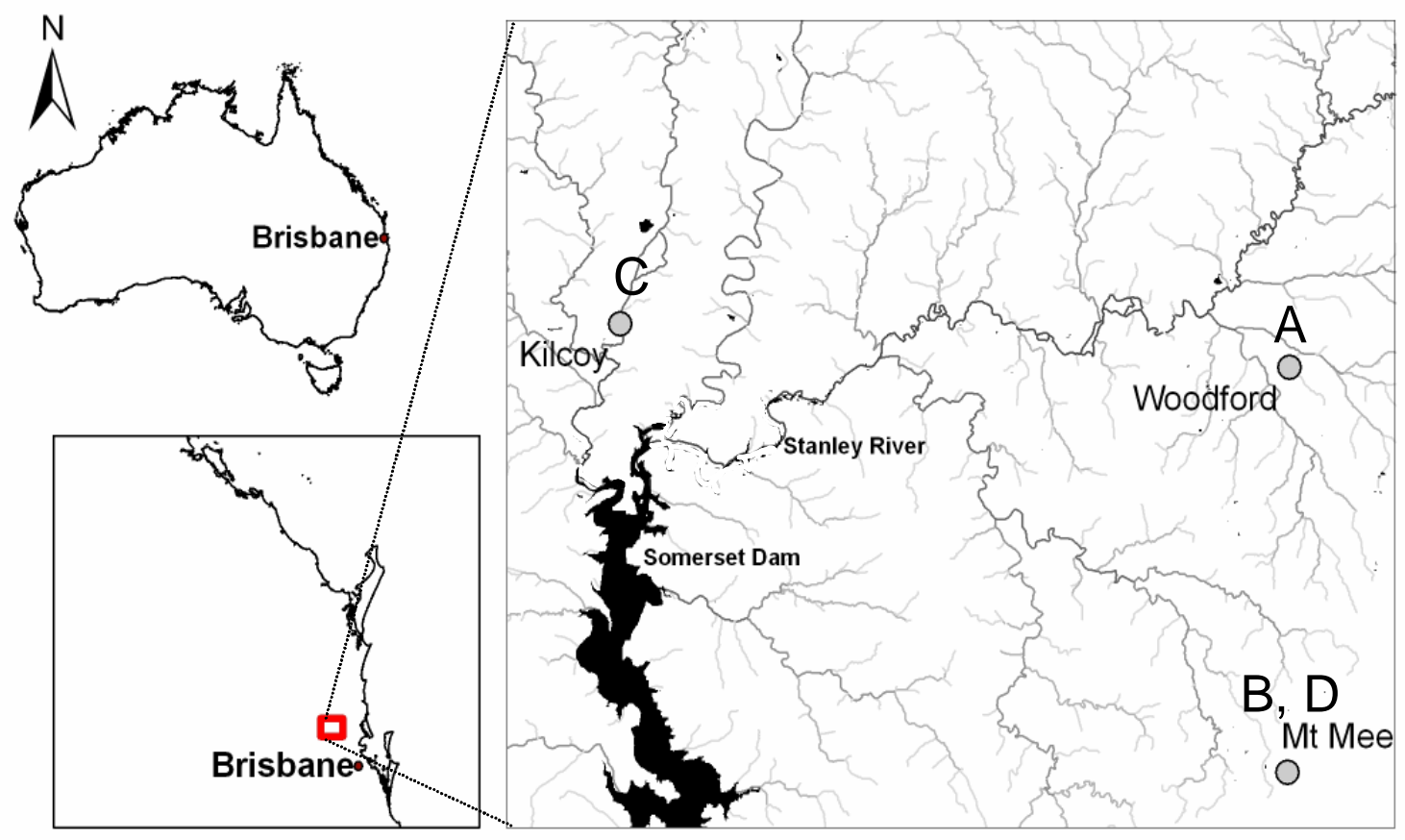

785

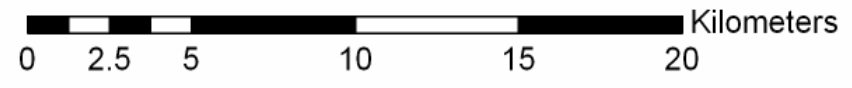

$786 \quad$ Figure 1 


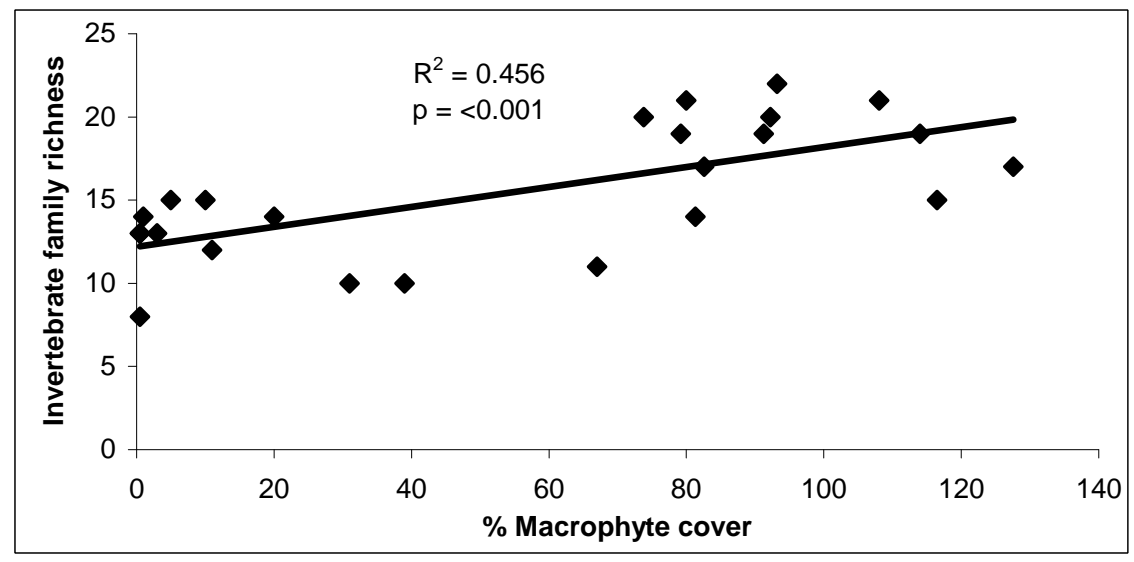

a)
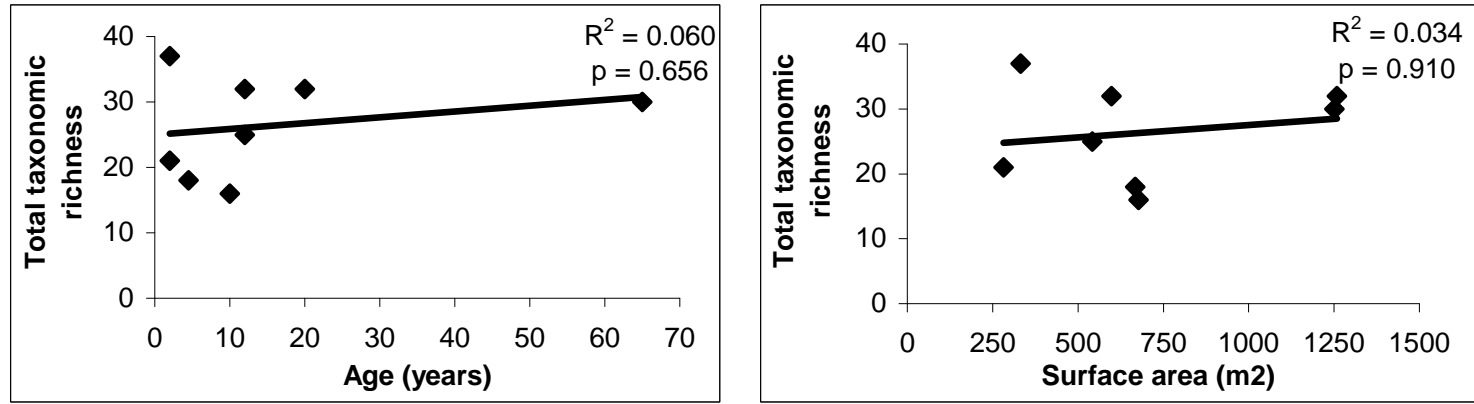

789

b)

$790 \quad$ Figure 2

791 
793

794

795

796

$797 \quad$ Figure 3

798

799

800

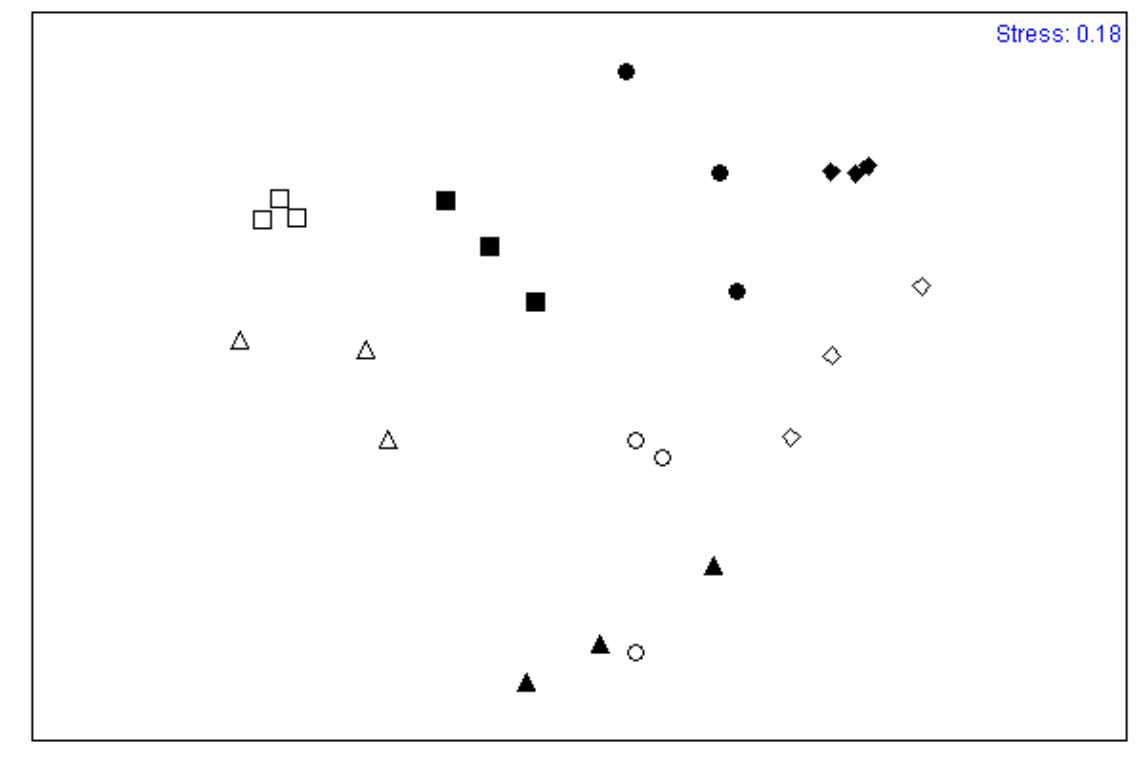

^ A1 $\triangle \mathrm{A} 2$

- $\begin{array}{lll}\text { - } & \square \quad \text { B2 }\end{array}$

- $\begin{array}{lll}\text { c1 } & \text { O } & \text { C2 }\end{array}$

$\bullet \quad$ D1 $\diamond \quad$ D2

a)
Stress: 0.18

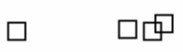

$$
\text { in }
$$

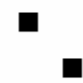

-

-

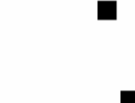

ロ

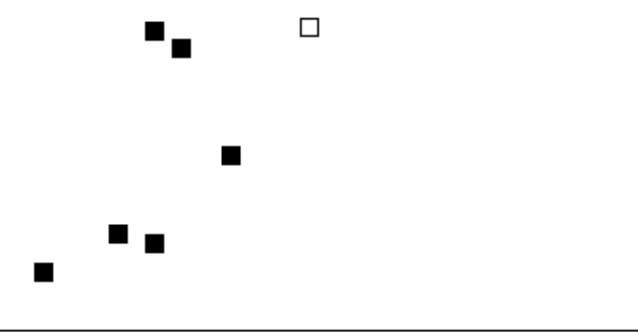

$\square$

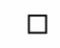

$\square$

b)
- Well Vegetated

$\square \quad$ Poorly Vegetated 


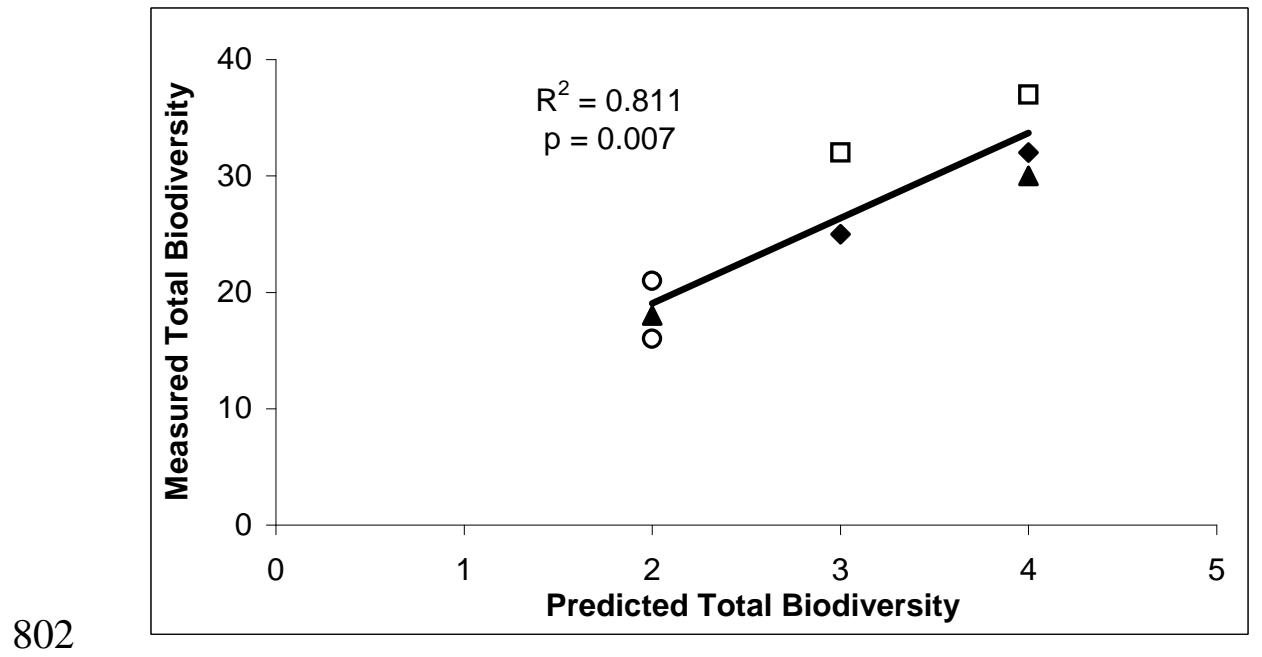

$803 \quad$ Figure 4 


\section{Tables}

805 Table 1: Summary of historical, morphological, water physical and chemical characteristics

806 and benthic metabolism data for each pond. Mean values are presented with associated

807 standard errors.

\begin{tabular}{|c|c|c|c|c|c|c|c|c|c|}
\hline POND ID & & $\mathbf{A 1}$ & $\mathbf{A 2}$ & B1 & $\mathbf{B 2}$ & $\mathbf{C 1}$ & $\mathbf{C 2}$ & D1 & D2 \\
\hline \multicolumn{10}{|l|}{ POND HISTORY } \\
\hline \multicolumn{2}{|l|}{ Age (years) } & 12 & 12 & 2 & 20 & 4.5 & 65 & 10 & 2 \\
\hline \multirow{2}{*}{\multicolumn{2}{|c|}{ Current management strategy }} & Riparian & None & Riparian & None & None & None & None & Fenced \\
\hline & & vegetation & & vegetation & & & & & \\
\hline \multicolumn{10}{|c|}{ MORPHOLOGICAL CHARACTERISTICS } \\
\hline \multicolumn{2}{|l|}{ Perimeter $(\mathrm{m})$} & 179.87 & 90.45 & 85.78 & 166.84 & 104.82 & 136.81 & 118.10 & 70.07 \\
\hline \multicolumn{2}{|l|}{ Surface area $(\mathrm{m})$} & 1258.56 & 542.05 & 332.11 & 597.48 & 667.35 & 1251.56 & 677.17 & 281.56 \\
\hline \multirow{3}{*}{$\begin{array}{l}\text { Littoral zone slope } \\
\text { ( } \Delta \text { depth/ } \Delta \text { distance from shore) }\end{array}$} & Mean & 0.28 & 0.19 & 0.39 & 0.39 & 0.22 & 0.25 & 0.24 & 0.55 \\
\hline & & & & & & & & & \\
\hline & SE & 0.14 & 0.02 & 0.05 & 0.08 & 0.03 & 0.04 & 0.03 & 0.11 \\
\hline \multirow[t]{2}{*}{ Deepest littoral zone depth $(\mathrm{cm})$} & Mean & 34.25 & 19.75 & 40.80 & 49.20 & 20.88 & 31.75 & 33.60 & 53.00 \\
\hline & SE & 12.35 & 2.39 & 5.89 & 9.06 & 0.97 & 5.81 & 6.05 & 11.02 \\
\hline \multicolumn{10}{|c|}{ PHYSICAL CHARACTERISTICS } \\
\hline \multicolumn{10}{|l|}{ Temperature } \\
\hline \multirow[t]{3}{*}{ Shallow } & Min & 9.9 & 11.8 & 14.1 & 14.1 & 12.4 & 13.0 & 10.8 & 11.0 \\
\hline & $\operatorname{Max}$ & 16.2 & 18.1 & 17.9 & 18.6 & 19.0 & 17.1 & 13.6 & 16.0 \\
\hline & Diel swing & 6.30 & 6.30 & 3.80 & 4.50 & 6.59 & 4.07 & 2.85 & 5.00 \\
\hline \multirow[t]{3}{*}{ Deep } & Min & 10.0 & 11.7 & 13.4 & 13.5 & 12.6 & 12.9 & 11.3 & 11.9 \\
\hline & $\operatorname{Max}$ & 10.3 & 12.7 & 14.3 & 14.3 & 14.2 & 14.8 & 13.4 & 13.3 \\
\hline & Diel swing & 0.30 & 0.98 & 0.86 & 0.80 & 1.60 & 1.90 & 2.16 & 1.40 \\
\hline \multicolumn{2}{|l|}{ Photic depth $(\mathrm{cm})$} & 136 & 122 & 295 & 455 & 69 & 223 & 192 & 331 \\
\hline \multicolumn{2}{|l|}{ Turbidity (NTU) } & 8.8 & 15.5 & 4.4 & 1.5 & 41.1 & 9.7 & 13.6 & 3.4 \\
\hline \multirow[t]{2}{*}{ Chlorophyll $a\left(\mathrm{mg} \mathrm{m}^{-2}\right)$} & Mean & 0.002 & 0.014 & 0.001 & 0.001 & 0.022 & 0.006 & 0.004 & 0.005 \\
\hline & SE & 0.001 & 0.004 & $<0.001$ & $<0.001$ & $<0.001$ & 0.001 & 0.001 & 0.001 \\
\hline \multicolumn{10}{|c|}{ CHEMICAL CHARACTERSTICS } \\
\hline \multicolumn{10}{|l|}{ Dissolved oxygen $\left(\mathrm{mg} \mathrm{L}^{-1}\right)$} \\
\hline \multirow[t]{3}{*}{ Shallow } & Min & 3.59 & 8.83 & 10.81 & 9.75 & 7.02 & 4.82 & 5.79 & 4.93 \\
\hline & $\operatorname{Max}$ & 5.53 & 10.09 & 12.81 & 13.62 & 8.97 & 7.89 & 7.03 & 7.57 \\
\hline & Diel swing & 1.94 & 1.26 & 1.99 & 3.87 & 1.95 & 3.07 & 1.24 & 2.64 \\
\hline Deep & Min & 3.05 & 8.96 & 6.20 & 11.70 & 6.97 & 4.30 & 5.56 & 5.74 \\
\hline
\end{tabular}




\begin{tabular}{|c|c|c|c|c|c|c|c|c|c|}
\hline & $\operatorname{Max}$ & 4.01 & 10.53 & 14.61 & 15.58 & 9.33 & 6.41 & 6.61 & 7.62 \\
\hline & Diel swing & 0.96 & 1.57 & 8.41 & 3.88 & 2.35 & 2.11 & 1.05 & 1.88 \\
\hline $\mathrm{pH}$ & & 6.32 & 6.02 & 7.75 & 7.95 & 6.25 & 5.73 & 7.23 & 6.59 \\
\hline Conductivity $\left(\mu \mathrm{S} \mathrm{cm}^{-1}\right)$ & & 518 & 125 & 614 & 680 & 116 & 135 & 623 & 740 \\
\hline Total phosphorus (mg L ${ }^{-1}$ ) & & 0.019 & 0.041 & 0.018 & 0.014 & 0.14 & 0.020 & 0.056 & 0.022 \\
\hline Filterable reactive rhosphorus & & $<0.002$ & $<0.002$ & 0.002 & 0.003 & 0.002 & $<0.002$ & 0.006 & 0.002 \\
\hline \multicolumn{10}{|l|}{$\left(\mathrm{mg} \mathrm{L}^{-1}\right)$} \\
\hline Ammonium-N $\left(\mathrm{mg} \mathrm{L}^{-1}\right)$ & & 0.006 & 0.010 & $<0.002$ & 0.003 & 0.015 & 0.002 & 0.80 & 0.029 \\
\hline Nitrate-N $\left(\mathrm{mg} \mathrm{L}^{-1}\right)$ & & 0.003 & $<0.002$ & $<0.002$ & 0.009 & 0.002 & $<0.002$ & 0.064 & 0.019 \\
\hline Total nitrogen $\left(\mathrm{mg} \mathrm{L}^{-1}\right)$ & & 0.46 & 1.2 & 0.31 & 0.29 & 1.5 & 0.45 & 1.8 & 0.38 \\
\hline \multicolumn{10}{|l|}{ BENTHIC METABOLISM } \\
\hline $\mathrm{R} \quad\left(\mathrm{mg} \mathrm{O}_{2} \mathrm{~m}^{-2} \mathrm{~h}^{-1}\right)$ & Mean & 49.94 & 79.27 & 251.61 & 103.96 & 112.22 & 125.54 & 155.92 & 134.96 \\
\hline \multirow{3}{*}{$\operatorname{NEP}\left(\mathrm{mg} \mathrm{O}_{2} \mathrm{~m}^{-2} \mathrm{~h}^{-1}\right)$} & SE & 7.10 & 23.68 & 10.52 & 7.86 & 3.87 & 4.40 & 8.39 & 34.70 \\
\hline & Mean & -10.46 & 14.44 & -73.37 & -63.76 & 91.69 & 83.03 & 91.40 & 30.37 \\
\hline & SE & 28.11 & 21.54 & 99.11 & 19.86 & 9.37 & 29.62 & 9.10 & 6.94 \\
\hline \multirow[t]{2}{*}{$\operatorname{GPP}\left(\mathrm{mg} \mathrm{O}_{2} \mathrm{~m}^{-2} \mathrm{~h}^{-1}\right)$} & Mean & 39.48 & 93.71 & 178.24 & 40.21 & 203.91 & 208.58 & 247.32 & 165.34 \\
\hline & SE & 21.85 & 16.25 & 88.59 & 14.39 & 11.18 & 32.36 & 17.35 & 41.64 \\
\hline \multirow[t]{2}{*}{ GPP/R } & Mean & 0.28 & 0.44 & 0.21 & 0.12 & 0.53 & 0.48 & 0.46 & 0.36 \\
\hline & SE & 0.13 & 0.12 & 0.11 & 0.04 & 0.02 & 0.07 & 0.01 & 0.00 \\
\hline
\end{tabular}


808 Table 2: Summary of macrophyte structure in farm pond littoral zones. Percent cover, species

809 richness and diversity values for each pond are the mean of three transects (SE). Total species

810 richness and introduced species are presented as the total number located in each pond. Ponds with

811 significantly $(\mathrm{p}<0.05)$ lower Total \% cover, mean species richness and mean species diversity are

812 indicated with * and are subsequently classified as poorly vegetated.

\begin{tabular}{|c|c|c|c|c|c|c|c|c|}
\hline POND ID & $\mathbf{A 1}$ & $\mathbf{A 2}$ & B1 & $\mathbf{B 2}$ & $\mathrm{C1}$ & $\mathbf{C 2}$ & D1 & D2 \\
\hline \% Emergent Cover & $65(1.7)$ & $37(9.3)$ & $4(1.9)$ & $1(0.8)$ & $0.5(0.3)$ & $54(7.8)$ & 0 & 0 \\
\hline$\%$ Floating Cover & $17(4.2)$ & 0 & $20(3.4)$ & $38(9.5)$ & 0 & $42(3.3)$ & $2(0.8)$ & 0 \\
\hline \% Submerged Cover & 0 & $9(4.8)$ & $64(4.5)$ & $69(8.5)$ & $3.5(3.2)$ & $6(4.1)$ & 0 & $12(4.4)$ \\
\hline Total \% Cover & $82(5.5)$ & $46(10.9)$ & $88(4.1)$ & $108(14.0)$ & $4(3.5) *$ & $102(9.6)$ & $2(0.8) *$ & $12(4.4) *$ \\
\hline Total Species Richness & 6 & 4 & 10 & 8 & 2 & 6 & 1 & 1 \\
\hline Introduced Species & 1 & 1 & 2 & 2 & 1 & 1 & 0 & 1 \\
\hline Mean Species Richness & $6.0(1.0)$ & $3.0(0.6)$ & $7.7(0.9)$ & $5.3(0.3)$ & $1.3(0.3) *$ & $5.7(0.3)$ & $1.0(0.0) *$ & $1.0(0.0) *$ \\
\hline Mean Diversity & $0.76(0.15)$ & $0.78(0.18)$ & $1.24(0.13)$ & $1.04(0.16)$ & $0.10(0.10) *$ & $1.27(0.07)$ & $0.00(0.00) *$ & $0.00(0.00) *$ \\
\hline
\end{tabular}


814 Table 3: Invertebrate family richness and diversity in littoral zones of the study ponds. Values shown

815 represent the total number of families identified from each order in each of the ponds. Total family

816 richness is given for each of the ponds as well as mean taxonomic richness and diversity based on

817 three replicate transect samples (SE). The last two columns show the total number of families

818 identified for each order across the eight study ponds and ten streams monitored by the Ecosystem

819 Health Monitoring Program (EHMP) sites in the Stanley River catchment. The total number of

820 families identified from all of the ponds and all of the streams are also presented.

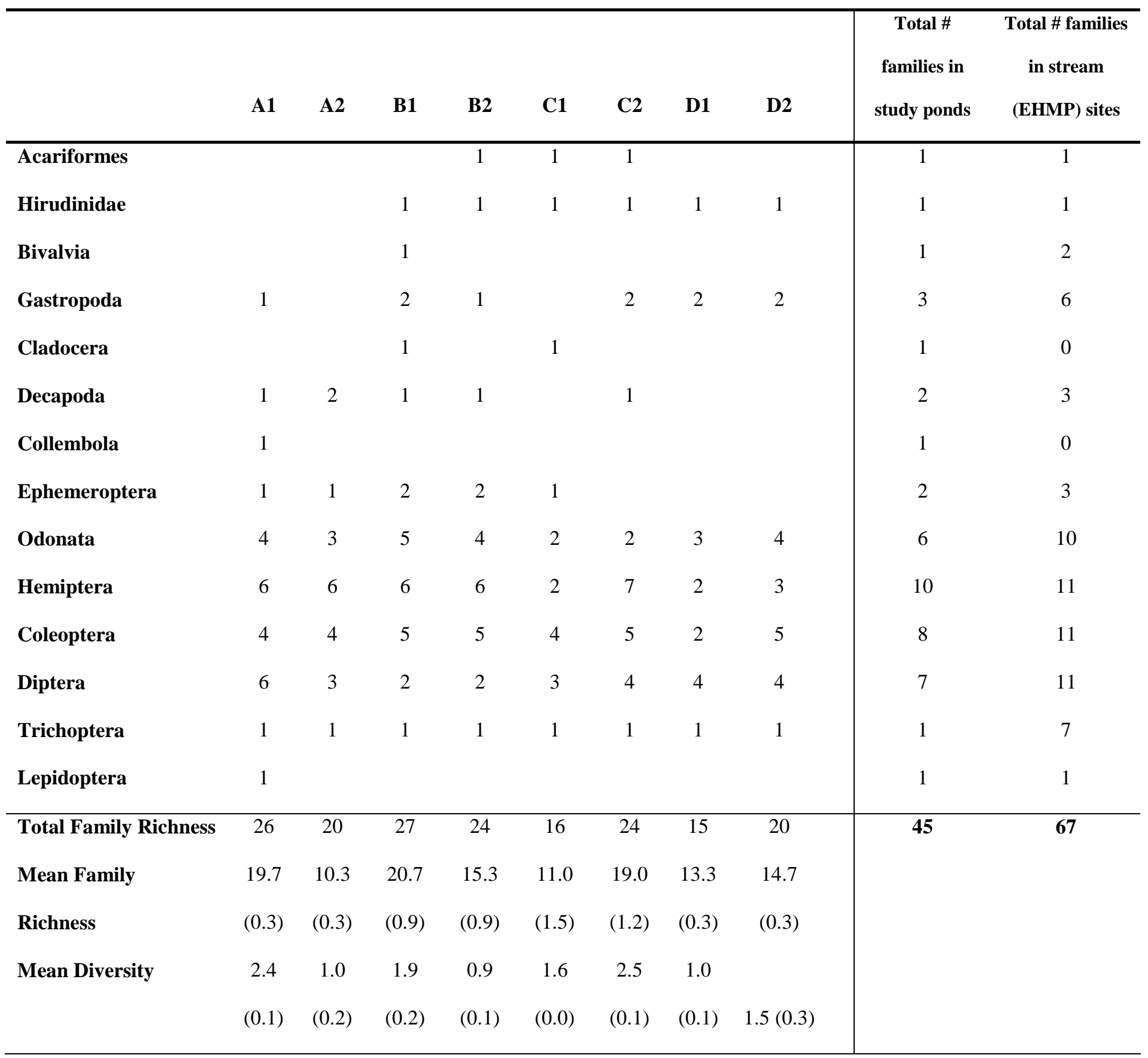


822 Table 4: Chemical and physical parameters measured in the study ponds compared to those measured

823 in other farm ponds in Australia. Values are shown as the minimum and maximum measurement of

824 each parameter.

\begin{tabular}{|c|c|c|c|}
\hline Chemical/Physical Parameter & Study Farm Ponds & $\begin{array}{c}\text { Brainwood and others } \\
\text { (2004) }\end{array}$ & $\begin{array}{c}\text { Hazell and others } \\
\text { (2001) }\end{array}$ \\
\hline Water column chlorophyll $a\left(\mu \mathrm{g} \mathrm{L}^{-1}\right)$ & $1-22$ & $0-390$ & \\
\hline $\mathrm{TP}\left(\mu \mathrm{g} \mathrm{P} \mathrm{L}^{-1}\right)$ & $14-140$ & $10-2800$ & \\
\hline $\operatorname{FRP}\left(\mu \mathrm{g} \mathrm{P} \mathrm{L}^{-1}\right)$ & $<2-6$ & & \\
\hline $\mathrm{TN}\left(\mu \mathrm{g} \mathrm{N} \mathrm{L}{ }^{-1}\right)$ & $290-1800$ & $0-9900$ & \\
\hline $\mathrm{NO}_{3}^{-}\left(\mu \mathrm{g} \mathrm{N} \mathrm{L}^{-1}\right)$ & $<2-64$ & $0-1600$ & \\
\hline $\mathrm{NH}_{4}^{+}\left(\mu \mathrm{g} \mathrm{N} \mathrm{L}^{-1}\right)$ & $<2-800$ & & \\
\hline $\mathrm{DO}\left(\mathrm{mg} \mathrm{L}^{-1}\right)$ & $3.05-15.58$ & $0.06-27$ & \\
\hline $\mathrm{pH}$ & $5.7-7.95$ & $6.6-9.3$ & $6.05-9.85$ \\
\hline Turbidity (NTU) & $1.5-41$ & $9.0-210$ & $10-400$ \\
\hline Temperature & 9.9-18.99 & $5.4-28$ & \\
\hline Conductivity $\left(\mu \mathrm{S} \mathrm{cm}^{-1}\right)$ & $115.5-740$ & $250-870$ & $25-964$ \\
\hline
\end{tabular}

825 